\title{
HUBUNGAN KONSUMSI KOPI DAN SCREEN-TIME DENGAN LAMA TIDUR DAN STATUS GIZI PADA DEWASA
}

\author{
Febiandra Kadita ${ }^{1}$, Hartanti Sandi Wijayanti ${ }^{1}$ \\ ${ }^{1}$ Departemen Ilmu Gizi Fakultas Kedokteran Universitas Diponegoro \\ Jln. Prof. H. Soedarto, SH., Semarang, Telp (024) 8453708, Email : gizifk@ undip.ac.id
}

\begin{abstract}
Background: Nutritional problem such as underweight or obesity in adolescents is an important issue that can lead into some disease. ${ }^{I}$ BMI can be affected with some factor, there were coffee consumption, screen-time and sleep duration. Sleep duration can be affected by coffee consumption and screen-time.

Objective: Knowing the relationship of coffee consumption and screen-time with sleep duration and BMI among Adult. Method: A cross-sectional study was conducted on 52 adult in Semarang Café. We measured weight and height as BMI $\left(\mathrm{kg} / \mathrm{m}^{2}\right)$. Subject interviewed about coffee consumption, screen-time, sleep duration and physical activity. Bivariate analysis used Pearson test and Rank-Spearman test. Multivariate analysis used Multivariate Linear Regression analysis of Backward.

Result: Bivariate analysis showed there was a significance relationship between coffee volume and night screen-time with sleep duration $(r=-0,3, p=0,03$ and $r=-0,3, p=0,01)$. There was a significance relationship between 1 day screen-time and physical activity with BMI $(r=0,2, p=0,04$ and $r=-0,27, p=0,04)$. Multivariate analysis showed there was a significance relationship between physical activity with $B M I(\beta=-0,26, p=0,05)$.

Conclusion: The volume of coffee consumption and screen-time was the factor that caused sleep deprivation. Physical activity was the factor of increased nutritional status.
\end{abstract}

Keyword: coffee consumption, screen-time, sleep duration, BMI

\section{ABSTRAK}

Latar Belakang: Masalah kekurangan dan kelebihan gizi pada usia dewasa merupakan masalah penting yang dapat memberikan resiko penyakit-penyakit. ${ }^{l}$ Status gizi dapat dipengaruhi beberapa faktor salah satunya adalah konsumsi kopi, screen-time dan lama tidur. Lama tidur juga dapat dipengaruhi oleh konsumsi kopi dan screen-time.

Tujuan: Mengetahui hubungan konsumsi kopi dan screen-time dengan lama tidur dan status gizi pada dewasa.

Metode: Rancangan penelitian adalah Cross-Sectional dengan jumlah subjek sebanyak 52 dewasa usia 18-25 tahun. Subjek diukur berat badan dan tinggi badan untuk menemukan Indeks Massa Tubuh $\left(\mathrm{kg} / \mathrm{m}^{2}\right)$. Kemudian dilakukan wawancara tentang konsumsi kopi, screen-time dan lama tidur. Konsumsi kopi dan screen-time ditetapkan sebagai variabel independen sedangkan lama tidur dan status gizi sebagai variabel dependen. Analisis bivariat menggunakan uji Rank Spearman dan Pearson. Analisis multivariat menggunakan uji Regresi Linier.

Hasil: Analisis bivariat menunjukkan ada hubungan yang signifikan antara volume kopi dan screen-time malam dengan lama tidur $(r=-0,3, p=0,03$ dan $r=-0,3, p=0,01)$. Terdapat hubungan yang signifikan antara screen-time 1 hari dan aktivitas fisik $(r=0,2, p=0,04$ dan $r=-0,27$ dan $p=0,04)$. Analisis multivariat menunjukkan hubungan yang signifikan pada aktivitas fisik dengan status gizi $(\beta=-0,26, p=0,05)$.

Kesimpulan: Volume kopi dan screen-time merupakan faktor terjadinya lama tidur yang rendah. Aktivitas fisik merupakan faktor terjadinya peningkatan status gizi.

Kata Kunci: konsumsi kopi, screen-time, lama tidur, status gizi

\section{PENDAHULUAN}

Status gizi normal mempunyai peranan penting terutama untuk usia harapan hidup yang lebih panjang, karena kekurangan atau kelebihan gizi pada usia dewasa memberikan resiko terhadap penyakitpenyakit tertentu dan menurunkan produktifitas kerja. ${ }^{1}$ Menurut Riset Kesehatan Dasar 2013, prevalensi dewasa kurus $8,7 \%$ berat badan lebih $13,5 \%$ dan obesitas $15,4 \%$. Masalah obesitas dan berat badan cenderung lebih tinggi di perkotaan. ${ }^{2}$

Lama tidur yang rendah memiliki hubungan dengan perubahan status gizi, sedangkan lama tidur yang rendah sedang menjadi endemik saat ini. ${ }^{3}$ Lama tidur yang rendah dapat mengakibatkan perubahan hormonal dan metabolisme yang berkontribusi pada kenaikan berat badan. ${ }^{4}$ Perubahan hormonal tersebut meliputi peningkatan hormon ghrelin dan penurunan kadar leptin sesuai dengan peningkatan rasa lapar dan nafsu makan. ${ }^{5}$ Hal ini terbukti pada studi yang menunjukkan bahwa dewasa yang kurang tidur memiliki kaitan dengan peningkatan berat badan karena terdapat peningkatan asupan kalori. ${ }^{3,5}$

Lama tidur dipengaruhi oleh screen-time. Screen-time pada usia dewasa sedang menjadi perhatian saat ini, terutama pada malam hari yang dapat menyebabkan menurunnya lama tidur. $^{6}$ Mengerjakan pekerjaan dan aktivitas hedonik seperti internet dan media sosial adalah penyebab dewasa 
menggunakan media elektronik pada malam hari. Paparan sinar pada media elektronik menyebabkan waspada berlebih dan mengganggu jam biologis tubuh sehingga membuat tidur lebih larut. ${ }^{7}$ Saat mata terpapar sinar media elektronik, terjadi penundaan pelepasan hormon melatonin. Hormon melatonin adalah hormon pengatur ritme tidur yang diproduksi di kelenjar pineal. Kelenjar ini berada pada otak serebri dimana dekat dengan mata sehingga sensitif dengan cahaya. ${ }^{8}$ Hal ini sesuai penelitian yang menyebutkan bahwa aktivitas screen-time pada malam hari berhubungan dengan lama tidur yang rendah.

Selain screen-time, lama tidur juga dapat dipengaruhi oleh konsumsi kopi. Kopi mempunyai kaitan dengan rendahnya lama tidur. Terdapat penelitian yang menunjukkan konsumsi kopi dapat membuat seseorang untuk susah tidur. Hal ini disebabkan kafein pada kopi yang dapat meningkatkan kewaspadaan, meningkatkan konsentrasi dan menurunkan rasa kantuk. ${ }^{9,7}$ Terdapat penelitian yang menunjukkan bahwa konsumsi kopi dapat membuat seseorang untuk susah tidur. ${ }^{10}$

Konsumsi kopi juga dapat mempengaruhi status gizi. Fungsi dari kopi yang menyebabkan terjadinya perubahan status gizi. Fungsi kopi yang dapat menyebabkan perubahan status gizi yaitu meningkatkan energi ekpenditur dan aktivitas lipotik pada tubuh. ${ }^{11}$ Kafein dapat meningkatkan aktivitas saraf simpatis yang menyebabkan peningkatan hormon lipolisis yaitu adrenalin, sehingga konsentrasi AMP siklik meningkat bahkan lebih besar daripada hormon itu sendiri. ${ }^{17}$ Penurunan berat badan karena konsumsi kopi dapat dirasakan dalam jangka panjang. Terdapat penelitian yang menunjukkan orang yang rutin mengkonsumsi kopi mempunyai Indeks Massa Tubuh (IMT) lebih rendah dbandingkan dengan yang tidak mengkonsumsi kopi. ${ }^{6}$ Terdapat penelitian lain yang menyatakan konsumsi kafein sebanyak $300 \mathrm{mg}$ per hari dapat meningkatkan energi ekspenditur hingga 79 kkal per hari. $^{12}$

Status gizi juga dapat dipengaruhi oleh screen-time. Screen-time pada kelompok usia dewasa awal meningkat drastis, terutama pada penggunaan smartphone. ${ }^{4}$ Terdapat penelitian yang menyebutkan menonton televisi dapat meningkatkan asupan makan, terutama makanan ringan, makanan berlemak dan makanan siap saji, sehingga terdapat peningkatan IMT pada usia dewasa. ${ }^{13}$ Terdapat temuan lain yang menyebutkan orang yang melakukan screen-time dalam satu hari mempunyai aktivitas fisik yang rendah. ${ }^{14}$ Hal ini disebabkan karena ketika seseorang melakukan screen-time, sebagian besar orang melakukannya dengan duduk. ${ }^{14}$ Kelebihan asupan makan dan tidak seimbang dengan penggunaan energi dapat menyebabkan peningkatan penyimpanan energi dan lemak dalam tubuh, sehingga terjadi peningkatan jumlah dan ukuran pada sel lemak. ${ }^{12}$

Tujuan penelitian ini adalah untuk mengetahui hubungan konsumsi kopi dan screentime dengan lama tidur dan status gizi pada dewasa. Penelitian ini dilakukan pada subjek berusia dewasa awal. Pemilihan subjek bergolongan usia dewasa awal karena konsumsi kopi dan screen-time pada golongan usia ini terbilang tinggi. Konsumsi kopi dan screen-time pada dewasa awal sudah menjadi kebutuhan sehari-hari, selain untuk penunjang pekerjaan juga sudah menjadi bagian dari gaya hidup pada dewasa awal.

\section{METODE}

Pengambilan data dilakukan di GB Café Semarang. Penelitian yang dilakukan merupakan penelitian dalam bidang ilmu gizi masyarakat. Penelitian ini merupakan penelitian observational dengan pendekatan cross sectional. Besar sampel dihitung menggunakan rumus perhitungan sampel dan didapatkan total sampel sebanyak 52 orang. Sampel dipilih dengan metode consecutive sampling.

Kriteria inklusi subjek antara lain dewasa usia 18-25 tahun, tidak mengkonsumsi obat yang dapat mempengaruhi tidur dan status gizi. Kriteria eksklusi subjek adalah bekerja shift malam, tidak berkenan mengikuti alur penelitian dan mengundurkan diri saat penelitian berlangsung. Skrining dilakukan untuk mendapatkan subjek yang sesuai dengan kriteria inklusi.

Variabel bebas (independen) dalam penelitian ini adalah konsumsi kopi dan screen-time, variabel terikat (dependen) adalah lama tidur dan status gizi, dan variabel perancu. Data yang dikumpulkan antara lain identitas subjek, berat badan (BB), tinggi badan (TB), IMT, data konsumsi kopi, data screen-time, data lama tidur, asupan makan dan aktivitas fisik.

Lama tidur yang dihitung adalah lama tidur saat tidur malam. Lama tidur memiliki beberapa kategori antara lain lama tidur kurang $(<7$ jam), lama tidur cukup (7-8jam) dan lama tidur lebih (>8jam). Aktivitas fisik dihitung menggunakan skor dari kuesioner short-IPAQ. Aktivitas fisik memiliki beberapa kategori antara lain aktivitas fisik rendah $(<600)$, cukup $(600-1500)$ dan lebih $(>1500)$. Pada aktivitas merokok, subjek dikatakan aktif merokok apabila merokok, dikatakan pasif apabila subjek tidak merokok namun menghirup asap rokok dari perokok aktif dan dikatakan tidak merokok apabila subjek tidak merokok dan tidak menghirup asap rokok.

Data identitas subjek diperoleh melalui wawancara. Penimbangan berat badan menggunakan timbangan injak digital dengan ketelitian $0,1 \mathrm{~kg}$. 
Pengukuran tinggi badan menggunakan microtoise dengan ketelitian $0,1 \mathrm{~cm}$. Data BB dan TB digunakan untuk menentukan status gizi. Data konsumsi kopi menggunakan kuesioner konsumsi kopi, data screentime menggunakan kuesioner screen-time, kuesioner lama tidur menggunakan Sleep Timing Questionnaire (STQ), dan kuesioner aktivitas fisik menggunakan Short-International Physical Activity Questionnaire (IPAQ).

Tahap pertama dalam penelitian ini adalah skrining subjek. Skrining dilakukan dengan menggunakan kuesioner. Subjek yang masuk kriteria inklusi dan setuju menjadi subjek penelitian mengisi informed consent. Tahap selanjutnya yaitu pengisian identitas yang diikuti dengan pengukuran antropometri berupa tinggi badan dan berat badan. Selanjutnya pengisian kuesioner terkait konsumsi kopi, screen-time, lama tidur, dan aktivitas fisik.

Analisis data menggunakan analisis komputer. Analisis univariat digunakan untuk mendeskripsikan karakteristik sampel berupa usia, jenis kelamin, kebiasaan merokok, konsumsi kopi, screen-time, lama tidur, dan aktivitas fisik. Data diuji normalitasnya dengan uji kolmogorov smirnov. Analisis bivariat digunakan untuk mengetahui hubungan masing-masing variabel bebas (kopi dan screen-time), dengan variabel terikat (lama tidur dan status gizi) menggunakan uji hubungan $r$-spearman atau pearson. Analisis multivariat menggunakan analisis regresi linier.

\section{HASIL PENELITIAN}

Karakteristik subjek dalam penelitian ini dapat dilihat pada tabel 1. Subjek penelitian berjumlah 52 orang yang terdiri dari 26 subjek (50\%) laki-laki dan 26 subjek (50\%) perempuan dengan rentang usia 18-25 tahun. Berdasarkan hasil pengukuran tinggi badan dan berat badan, diketahui IMT 23 subjek $(44,23 \%)$ adalah normal dengan rerata $22 \pm 3,18 \mathrm{~kg} / \mathrm{m}^{2}$. Sebagian besar subjek adalah perokok aktif dengan jumlah 33 subjek $(63,46 \%)$.

Berdasarkan hasil wawancara, diketahui 28 subjek $(49,1 \%)$ mengkonsumsi kopi pada waktu malam hari dengan rentang waktu 18.00-04.59. Pada lama tidur diketahui 39 subjek (75\%) memiliki rerata lama tidur 5,71 $\pm 1,13 \mathrm{jam} / \mathrm{malam}$. Berdasarkan hasil tersebut maka diketahui sebagian besar subjek memiliki lama tidur yang rendah ( $<7 \mathrm{jam} / \mathrm{malam})$. Pada skor aktivitas fisik, diketahui 52 subjek (100\%) memiliki rerata skor aktivitas fisik 427,5 $\pm 62,5$. Hal ini menunjukkan bahwa seluruh subjek memiliki skor aktivitas fisik yang rendah $(<600)$.

\begin{tabular}{lc}
\multicolumn{2}{c}{ Tabel 1. Karakteristik Subjek } \\
\hline Variabel & $\%$ \\
\hline Jenis Kelamin & 50 \\
Laki-laki & 50 \\
Perempuan & \\
Status Gizi & 21,1 \\
Underweight & 44,2 \\
Normal & 21,1 \\
Overweight & 13,5 \\
Obesitas & \\
Waktu Konsumsi Kopi & 21 \\
Pagi $(05.00-09.59)$ & 8,7 \\
Siang (10.00-14.59) & 21 \\
Sore (15.00-17.59) & 49,1 \\
Malam (18.00-04.59) & \\
Rokok & 63,46 \\
Perokok Aktif & 34,6 \\
Perokok Pasif & 1,92 \\
Tidak Perokok & \\
Lama Tidur & 75 \\
Kurang (<7jam) & 25 \\
Cukup (7-8jam) & \\
Aktifitas Fisik & 100 \\
Kurang (<600) & \\
\hline
\end{tabular}

Pada konsumsi kopi, diketahui terdapat subjek yang mengkonsumsi kopi rutin lebih dari $1 \mathrm{x} /$ hari misal mengkonsumsi kopi pada pagi dan sore hari. Pada frekuensi kopi memiliki nilai tengah $7 \mathrm{x} /$ hari dan rerata volume kopi yaitu $171,85 \pm 1,17 \mathrm{ml} /$ hari. Screen-time 1 hari diketahui memiliki nilai tengah $13 \mathrm{jam} / \mathrm{hari}$ dan screen-time malam malam memiliki rerata $3,3 \pm 1,31 \mathrm{jam} / \mathrm{malam}$.

Tabel 2. Deskripsi Status Gizi, Konsumsi Kopi, Screen-Time dalam 1 hari, Screen-Time Malam, Lama tidur dan Aktivitas Fisik

\begin{tabular}{lcccc}
\hline Variabel & Mean \pm SD & Median & Min & Maks \\
\hline Status Gizi $\left(\mathrm{kg} / \mathrm{m}^{2}\right)$ & $22 \pm 3,18$ & 22,35 & 16,5 & 27,8 \\
Konsumsi Kopi & & & & \\
$\quad$ Frekuensi Kopi (x/mgg) & $5,58 \pm 3,3$ & 7 & 0,5 & 14 \\
$\quad$ Volume Kopi (ml/hr) & $171,85 \pm 1,17$ & 160,9 & 7 & 600 \\
Screen-Time dalam 1 hari (jam/hr) & $12.5 \pm 2.32$ & 13 & 7 & 17 \\
Screen-Time Malam (jam/mlm) & $3,3 \pm 1,31$ & 3,14 & 0,85 & 6 \\
Lama Tidur (jam/mlm) & $5,71 \pm 1,13$ & 5,46 & 3,57 & 8,42 \\
Aktivitas Fisik & $427,5 \pm 62,5$ & 422,5 & 280 & 583 \\
\hline
\end{tabular}


Hubungan Konsumsi Kopi dan Screen-Time Malam dengan Lama Tidur

Tabel 3 menunjukkan hubungan konsumsi kopi dan screen-time malam dengan lama tidur. Berdasarkan tabel, diketahui konsumsi kopi menurut frekuensi tidak memiliki hubungan dengan lama tidur ( $>0,05)$. Volume kopi diketahui memiliki hubungan yang signifikan dengan lama tidur $(\mathrm{p}<0,05)$ dimana semakin tinggi volume kopi yang dikonsumsi maka semakin rendah lama tidur. Screen-time malam memiliki hubungan yang signifikan dengan lama tidur $(\mathrm{p}<0,05)$ dimana semakin tinggi screen-time malam maka semakin rendah lama tidurnya.

Tabel 3. Hubungan Konsumsi Kopi dan Screen-Time Malam dengan Lama Tidur

\begin{tabular}{lcc}
\hline \multicolumn{1}{c}{ Variabel } & \multicolumn{2}{c}{ Lama Tidur } \\
\cline { 2 - 3 } \multicolumn{1}{c}{ Frekuensi Kopi } & $\mathbf{r}$ & $\boldsymbol{p}$ \\
Volume Kopi & $-0,2$ & $0,1^{1}$ \\
Screen-Time Malam & $-0,3$ & $0,03^{1}$ \\
\hline
\end{tabular}

${ }^{1}$ Uji Korelasi Rank-Spearman

Hubungan Konsumsi Kopi, Screen-Time dalam 1 Hari, Aktivitas Fisik dan Lama Tidur dengan Status Gizi

Tabel 4 menunjukkan hubungan konsumsi kopi, screen-time dalam 1 hari dan lama tidur dengan status gizi. Berdasarkan tabel korelasi tersebut, diketahui frekuensi kopi, volume kopi dan lama tidak memiliki hubungan dengan status gizi $(p>0,05)$. Pada screen-time 1 hari ditemukan memiliki hubungan yang signifikan dengan status gizi $(\mathrm{p}<0,05)$ dimana semakin tinggi screen-time 1 hari maka semakin tinggi status gizi. Aktivitas fisik ditemukan memiliki hubungan yang signifikan dengan status gizi $(\mathrm{p}<0,05)$ dimana semakin rendah aktivitas fisik maka semakin tinggi status gizi.

Tabel 4. Hubungan Konsumsi Kopi dan Screen-Time dengan Status Gizi

\begin{tabular}{lcc}
\hline \multicolumn{1}{c}{ Variabel } & \multicolumn{2}{c}{ Status Gizi } \\
\cline { 2 - 3 } & r & $\boldsymbol{p}$ \\
\hline Frekuensi Kopi & 0,08 & $0,5^{1}$ \\
Volume Kopi & 0,2 & $0,1^{1}$ \\
Screen-Time 1 hari & 0,2 & $0,04^{2}$ \\
Lama Tidur & $-0,25$ & $0,07^{2}$ \\
Aktivitas Fisik & $-0,27$ & $0,04^{1}$ \\
\hline
\end{tabular}

${ }^{1}$ Uji Korelasi Pearson; ${ }^{2}$ Uji Korelasi Rank-Spearman

Tabel 5 menunjukkan analisis multivariat antara screen-time 1 hari, lama tidur dan aktivitas fisik dengan status gizi. Berdasarkan tabel, didapatkan hasil bahwa aktivitas fisik mempunyai hubungan yang kuat dengan status gizi $(\beta,-0,26 ; p$, $0,05)$. Nilai $\mathrm{p}=0,05$ menunjukkan signifikansi pengaruh screen-time 1 hari dan aktivitas fisik dengan status gizi. Model regresi linier ini memiliki nilai $R^{2}$ sebesar $16,6 \%$. Artinya volume kopi, screen-time 1 hari, lama tidur dan aktivitas fisik memiliki pengaruh sebesar $16,6 \%$ pada status gizi.

Tabel 5. Analisis Multivariat Antara Volume Kopi, Screen-Time 1 hari, Lama Tidur dan Aktivitas Fisik dengan Status Gizi

\begin{tabular}{lccc}
\hline \multicolumn{1}{c}{ Variabel } & Koefisien $(\boldsymbol{\beta})$ & $\boldsymbol{p}$ & Adjusted R-Square \\
\hline Volume Kopi & 0,1 & $0,4^{1}$ & \multirow{2}{*}{0,166} \\
Lama Tidur & $-0,2$ & $0,13^{1}$ & \\
Screen-Time 1 hari & 0,23 & $0,08^{1}$ & \\
Aktivitas Fisik & $-0,26$ & $0,05^{1}$ & \\
\hline
\end{tabular}

${ }^{1}$ Uji Regresi Linier

\section{PEMBAHASAN}

Penelitian ini dilakukan pada 52 subjek di GB Café Semarang untuk mengetahui hubungan konsumsi kopi dan screen-time dengan lama tidur dan status gizi pada dewasa. Hasil penelitian menemukan bahwa terdapat hubungan yang signifikan pada volume kopi dan screen-time malam dengan lama tidur. Screen-time 1 hari memiliki hubungan yang signifikan dengan status gizi dan konsumsi kopi tidak memiliki hubungan dengan status gizi.

Frekuensi kopi tidak memiliki hubungan dengan lama tidur $(p>0,05)$. Nilai tengah frekuensi konsumsi kopi adalah $7 \mathrm{x} /$ minggu. Terdapat penelitian yang menyebutkan kopi yang dikonsumsi rutin 
memberi efek gangguan tidur hanya sedikit bahkan pada orang yang mengkonsumsi kopi 6-7 kali per hari. ${ }^{7}$ Hal ini dapat terjadi karena kafein yang rutin dikonsumsi menyebabkan terjadinya peningkatan pada hormon adenosin di bagian otak dengan membentuk koloni, sehingga tubuh menjadi toleran dengan kafein. ${ }^{18}$ Hormon adenosin berfungsi sebagai relaksasi tubuh.

Namun sebaliknya, volume kopi memiliki hubungan yang signifikan dengan lama tidur $(\mathrm{p}=0,03)$. Hal ini sesuai dengan temuan yang menyebutkan bahwa satu cangkir kopi $(220 \mathrm{ml})$ memiliki kandungan kafein sebesar $100 \mathrm{mg}$ dapat mengganggu kualitas tidur, memperpanjang latensi tidur dan meningkatkan frekuensi untuk terbangun di tengan malam secara signifikan. ${ }^{9}$ Pada penelitian ini diketahui rerata volume kopi yaitu $171,85 \pm 1,17 \mathrm{ml} / \mathrm{hari}$ dimana lebih rendah dari satu cangkir kopi. Meskipun terbilang lebih rendah dari satu cangkir kopi, namun subjek mengkonsumsi kopi saat mendekati waktu tidur. Terdapat temuan yang menyebutkan mengkonsumsi kopi 3 jam sebelum tidur dapat mengurangi lama tidur hingga 3 jam. ${ }^{13} \mathrm{Hal}$ ini dapat terjadi karena ketika kafein masuk ke tubuh, kafein akan menghambat pelepasan hormon adenosin yang berfungsi sebagai relaksasi. Susunan rantai kafein yang hampir sama dengan hormon adenosin menyebabkan kafein masuk ke reseptor adenosin dan menjadi reseptor adenosin antagonis. ${ }^{18}$ Adenosin antagonis tersebut kemudian masuk ke dalam saraf simpatis yang terdapat dopamin, sehingga tekanan darah, denyut jantung, kewaspasdaan meningkat dan menjadi aditif dengan kafein. ${ }^{18}$ Konsentrasi kafein akan maksimal di dalam tubuh setelah 6 jam setelah konsumsi dan efek puncak kafein terjadi selama 1545 menit setelah konsumsi. ${ }^{15}$ Karena subjek mengkonsumsi kopi mendekati waktu tidur yaitu mengkonsumsi pada jam sore dan malam, maka lama tidur subjek akan terganggu karena kerja kafein. Hal ini terbukti pada sebuah temuan yang menyebutkan bahwa konsumsi kopi mendekati waktu tidur dapat meningkatkan latensi tidur dan menurunkan lama tidur. ${ }^{7}$ Pada penelitian ini rerata lama tidur subjek yaitu $5,71 \pm 1,13 \mathrm{jam} / \mathrm{malam}$ dimana tergolong rendah (<7jam/malam).

Selain volume kopi, screen-time malam memiliki hubungan dengan lama tidur $(\mathrm{p}=0,01)$. Hal ini sesuai dengan penelitian yang menyebutkan screen-time pada malam hari mempunyai kaitan dengan menurunnya lama tidur seiring dengan meningkatnya screen-time. ${ }^{6}$ Pada penelitian ini diketahui rerata screen-time malam subjek yaitu $3,3 \pm 1,31 \mathrm{jam} / \mathrm{malam}$. Subjek melakukan screen-time malam untuk mengerjakan pekerjaan, komunikasi, media sosial dan hiburan. Penggunaan media elektronik pada malam hari berkontribusi pada gangguan tidur melalui paparan layar media elektronik yang dapat menyebabkan waspada berlebih dan menyebabkan terganggunya jam biologis tubuh. ${ }^{4}$ Paparan sinar dari media elektronik menyebabkan hormon melatonin meningkat, sehingga membuat seseorang untuk terbangun pada malam hari. ${ }^{8}$

Konsumsi kopi baik menurut frekuensi maupun volume tidak memiliki hubungan dengan status gizi $(p>0,05)$. Sedangkan untuk dapat mempengaruhi status gizi, frekuensi dan volume konsumsi kopi saling mempengaruhi. Menurut penelitian, konsumsi kafein sebanyak $300 \mathrm{mg} /$ hari dapat meningkatkan energi ekspenditur hingga 79 kkal per hari. ${ }^{11}$ Namun efek ini hanya akan dirasakan pada jangka waktu minimal 6 bulan dengan mengkonsumsi secara rutin dengan kisaran volume 100-400mg kafein per hari. ${ }^{16,17}$ Rerata volume yang dikonsumsi subjek kurang dari satu cangkir $(171,85 \pm 1,17 \mathrm{ml} / \mathrm{hari})$, dimana kurang dari satu cangkir kopi yaitu $200 \mathrm{ml}$ yang mengandung $100 \mathrm{mg}$ kafein.

Lama tidur tidak berhubungan dengan status gizi $(\mathrm{p}=0,06)$. Terdapat penelitian yang menyebutkan bahwa lama tidur yang rendah akan memicu peningkatan berat badan akibat perubahan hormon ghrelin dan leptin yang akan membuat seseorang untuk lapar. ${ }^{5}$ Pada peneliian ini, makanan yang dikonsumsi pada malam hari dapat meningkatkan asupan energi, namun karena subjek mengkonsumsi makanan yang rendah kalori seperti buah-buahan atau mengkonsumsi dalam jumlah yang sedikit, maka hubungan lama tidur dengan status gizi tidak signifikan.

Analisis bivariat menunjukkan terdapat hubungan yang signifikan antara screen-time 1 hari dengan status gizi. Hal ini sesuai dengan penelitian yang menyebutkan ketika individu menggunakan media elektronik, maka aktivitas fisik dapat menurun dan status gizi meningkat. ${ }^{12}$ Pada analisis multivariat tidak ditemukan hubungan pada screen-time 1 hari dengan status gizi. Hal ini disebabkan karena aktivitas fisik merupakan faktor yang lebih dominan daripada screen-time 1 hari. Terdapat penelitian yang menyebutkan tidak ditemukannya aktivitas fisik saat screen-time, hal ini dapat terjadi karena saat screentime orang akan cenderung melakukannya dengan berdiri, duduk atau bahkan berbaring. ${ }^{14}$ Aktvitas fisik yang rendah dapat meningkatkan status gizi dikarenakan terjadinya ketidak seimbangan energi pada tubuh. Ketika energi yang masuk tidak sesuai dengan energi yang dikeluarkan, maka energi yang masuk tersebut disimpan dalam tubuh dalam bentuk lemak pada jaringan adiposit. 


\section{KESIMPULAN}

Terdapat hubungan yang signifikan antara volume konsumsi kopi dan screen-time malam dengan lama tidur, dimana semakin tinggi volume konsumsi kopi dan screen-time malam maka semakin rendah lama tidur. Terdapat hubungan yang signifikan antara aktivitas fisik dan status gizi.

\section{SARAN}

Diperlukan edukasi tentang konsumsi kopi yang tepat yaitu pada pagi hari. Selain itu diperlukan edukasi untuk memperbaiki pola tidur yaitu dengan menjauhkan media elektronik portabel seperti handphone berada di kasur dan menghindari menggunakan media elektronik di kamar.

\section{UCAPAN TERIMAKASIH}

Puji dan syukur penulis panjatkan kehadirat Allah SWT atas segala rahmat dan karunia yang telah diberikan kepada penulis. Terimakasih kepada seluruh pengunjung Café GB telah berkenan untuk menjadi subjek penelitian. Kepada pemilik Café GB yang telah memberikan ijin dalam melaksanakan penelitian. Penulis juga mengucapkan terima kasih kepada seluruh pihak yang telah membantu dan memberikan dukungan dalam penelitian ini.

\section{DAFTAR PUSTAKA}

1. Kementerian Kesehatan. Pedoman Praktis Memantau Status Gizi Orang Dewasa. Jakarta: Departemen Kesehatan RI.

2. Badan Penelitian dan Pengembangan Kesehatan. Riset Kesehatan Dasar 2013. Jakarta: Kementerian Kesehatan RI.

3. Hele L, Magee L. Longitudinal assocoations between sleep duration and subsequent weight gain: A systematic review. ELSEVIER Sleep Medicine Reviews. 16 (2012):231-241.

4. T. M. Wendy, G Hunter, S Deborah. Say "GDNT":frequency of adolescent texting at night. Sleep Health (2015):300-303.

5. Chaput JP, Tremblay. Insufficient Sleep as a Contributor to Weight Gain : An Update. Metabolic Health. Curr Obes Rep 1(2012):245-256

6. Hysing M, Pallesen S, Stormark KM, Jakobsen R, Kundervold AJ, Siversten B. Sleep and use of devices in adolescence: results from a large population-based study. BMJ Open (2015):1-8.(6)

7. Lorist M M, Snel J. Caffeine, Sleep and Quality of Life. Sleep and Quality of Life in Clinical Medicine. (33):325-332.9

8. Falbe J, Davison KK, Franckle RL, Ganter C, Gortmaker SL, Smith L, Land T, Taveras EM. Sleep Duration, Restfullness, and Screens in the Sleep Environment. PEDIATRICS 2015;2(135):1-9.

9. Linares C L, Lafuente C L, Chassany O, Green A, Delcey V, Mouly S, Bermann J F. Does a single cup of coffee at dinner alter the sleep? A controlled cross- over randomised trial in real-life conditions. Nutrition and Dietetics : 1-6.8

10. Your Guide to Healthy Sleep. United States of America: National Institutes of Health.

11. Ludwig IA, Clifford MN, Lean MEJ, Ashihara H, Crozier A. Coffee: biochemistry and potential impact on health. Food Func. DOI: 10.1039/c4fo00042k.

12. James WPT, Leach RJ, Mhurchu CN, Kalamara E, Shayeghi M, Rigby NJ, Nishida C, Rodgers A. Overweight and Obesity (High Body Mass Index). Food Func 2014.

13. Cameron J D, Maras D, Sigal R J, Kenny G P, Borghese M M, Chaput J P, Alberga A S, Goldfield $\mathrm{G} S$. The mediating role of energy intake on the relationship between screen time behaviour and body mass index in adolescents with obesity: The HEARTY study. Appetite (2016):437-444.

14. Davies CA, Vandelanotte C, Duncan MJ, Uffelen JGZ. Association of physical activity and screen-time on health related quality of life in adults. Preventive Medicine. 55(2012):46-49.

15. Drake C, Roehrs T, Shambroom J, Roth T. Caffeine Effects on Sleep Taken 0, 3, or 6 Hours before Going to Bed. Journal of Clinical Sleep Medicine 2013;9(11):1195-1200.

16. Rudelle S, Ferruzzi MG, Cristiani I, Moulin J, Mace K, Acheson KJ, Tappy L. Effect of a Thermogenic Beverage on 24-Hour Energy Metabolism in Humans. OBESITY 2007;2(15):349-355.

17. Acheson KJ, Fremaud G, Meirim I, Montigon F, Krebs Y, Fay LB, Gay LJ, Schneiter P, Schindler C, Tappy L. Metabolic effects of caffeine in humans: lipid oxidation or furtile cycling? Am J Clin Nutr 2004;79:40-46.

18. Ammon HPT. Biochemical of Caffeine Tolerance. Arch Pharm 2005;324:261-267. 